\title{
KAROL WOJTYLA'S PHILOSOPHY OF THE HUMAN PERSON AND THE FILIPINO CONTEMPORARY SOCIETAL ISSUES
}

\author{
Glenn G. Pajares \\ University of San Jose - Recoletos, Cebu City, Philippines
}

\begin{abstract}
The contemporary Philippine society is flooded with various concerns and issues such as drug abuse, extrajudicial killings of the War on Drugs, HIV and AIDS, fake news, and human-induced climate change, among others. This predicament can be attributed not only to the degradation of ethics and values but basically to the deterioration of the philosophy of the human person; that is, the lack if not a distortion of the Filipino's understanding of what man truly is. By using content analysis, this paper delves into Karol Wojtyla's Philosophy of the Human Person as a means to help address and rectify the said distorted outlook of the human person as the root cause of the many issues of contemporary Philippine society. It allows the Filipino to understand himself and others as a human person who, according to Wojtyla, is created in God's image and likeness, a subject and not an object, a substantial amalgamation of body and soul, endowed with the faculties of intellect and will, a conscious and free-efficient cause or agent of his actions. Therefore, a moral being capable of moral choices, who seek the Truth and the Good as the basis of his decisions, and a social being who is responsible and accountable for his actions as well as a steward of the environment and the whole of creation.
\end{abstract}

\section{INTRODUCTION}

The Philippine Contemporary Society is confronted by a myriad of social, political, economic, and environmental problems such as Drug Abuse, extrajudicial killing relative to the Drug War of Duterte's Administration, the rapid and escalating spread of HIV and AIDS, the proliferation of fake news, and human-induced climate change among others. These problems are not just known abstractly but are experienced by the Filipinos in their day-to-day life.

All these problems are undeniably ethical or moral because they are products of human acts that are conscious, free, and voluntary. Moral and ethical issues boil down to the problem of philosophical anthropology or the crisis of the Philosophy of the Human Person primarily because the human person is the efficient cause, the liable agent as well as the recipient of all his/her actions. According to Jove Jim Aguas (2009, 
1), the human person is both the culprit and the victim. Secondly, all these problems indicate the lack or distorted understanding of oneself and others as human persons or the failure of the human person to acknowledge his dignity and dignity of others. Simon Nolan (n.d., 12) stresses that John Paul II himself saw the crisis of the modern age as a crisis of humanism. Alice Ramos $(1995,114)$ and George Weigel (n.d.) claim that for John Paul II, the present moral or ethical problem is caused by an anthropological turmoil, which is a metaphysical crisis where one fails to transcend appearances and to look into the very essence of the human person where human dignity rests.

All these problems of Contemporary Philippine society reveal the Filipino's lack of understanding of the true essence of the human person. Consequently, this crisis calls for an immediate response to fill in the gap by helping every Filipino understand and remember his or her authentic essence as a human person. This daunting task is a primordial duty not just of the Catholic Church in the Philippines, of Philippine Catholic education institutions, of philosophical associations promoting Christian Philosophy, but a task every Filipino must bear. To fulfill this task requires the reeducation of the Filipino on philosophical anthropology. But the question is, which philosophy of the human person will be used considering that there are so many of them in the history of Philosophy? Karol Wojtyla's or John Paull II's thought on the human person is very relevant to the Filipinos. Therefore, it serves as an appropriate source, framework, model, and foundation for the said purpose.

Foremost, Wojtyla or John Paul II is a Catholic priest, pope, and saint, which makes him very close and relevant to the Filipino Nation, which is the only Catholic nation in Asia. Second, his thoughts apply even to non-Catholics and non-Christian Filipinos because, according to Cardinal Nasrallah Pierre Sfeir (2003), John Paul II is a champion of ecumenism and inter-faith or inter-religious dialogue. Third, Marielle Medina and Antonio Rafael (2014) mention that John Paul II is the only pope who visited the Philippines twice in his papacy. In fact, in one of his visits, specifically the second one, he mentioned that the Filipinos are close to his heart. Moreover, in these two visits to the country, he was welcomed by the Filipinos like a rock star drawing one of the most massive crowds in the history of papal visits, which is a manifestation of the Filipinos' love for the pope. Furthermore, his background in the AristotelianThomistic philosophical tradition makes him very significant and relevant to Filipino philosophers and scholars who are mostly products of Catholic major seminaries and universities whose curricula are grounded on Aristotelian and Thomistic philosophy. Finally, he is relevant even to contemporary Filipino thinkers who are products of modern and contemporary philosophy because he is a contemporary thinker himself with a good background in Phenomenology, a postmodern or contemporary philosophical method, trend, and school of thought.

Based on the reasons above, this paper aims to utilize Karol Wojtyla's or John Paull II's Philosophy of the Human Person as a source, framework, model, and foundation to reeducate the Filipino on his genuine nature as a human person to profoundly understand, value, treat oneself and others as human persons so as to address the select moral ills of contemporary Philippine society namely, Drug Abuse, the Drug War, HIV and AIDS, Fake News, and Human-Induced Climate Change. In this paper, the names Karol Wojtyla and John Paul II are used interchangeably. 


\section{THE DRUG ABUSE IN THE PHILIPPINES AND KAROL WOJTYLA'S PHILOSOPHY OF THE HUMAN PERSON}

Jonathan de Santos (2019) reports that the leading government agencies in the Philippines involved in the battle against illegal drugs such as the National Bureau of Investigation (NBI), The Philippine National Police (PNP), The Philippine Drug Enforcement Agency (PDEA), unanimously agree with President Rodrigo Duterte that there is now an estimated eight million victims of drug abuse in the country which is higher than the four million estimates by the president in 2017. Mariano S. Hembra (2004) articulates that though the predominance of illegal drugs in the country is very much contested by the opposition and the critics of the Duterte administration and it has not been determined accurately, the government has considered it to have reached an epidemic level and has been one of its priority agenda. Juzel Danganan (2017) utters that whether the existing data of estimated drug users in the country is accurate or inaccurate, drug addiction or drug abuse, for sure, has relentlessly affected Philippine society throughout demographics and economic strata. It is a social threat that may result in countless crimes, financial problems, severed relationships among family members and friends.

Pope John Paul II $(1987,1)$ in his speech to the representatives of the International Convention on Drug Abuse and Illicit Trafficking, considers drug abuse as one of the overwhelming tragedies of contemporary society which permeates in all corners of the world in an increasing and widening proportions that afflict people of all ages, race, profession and walk in life. What is frightening is that it afflicts the young who are the future of every nation. The pope compares drug abuse to a scourge, famine, a drought, or an epidemic, in other words, an evil, an absence of truth, and Good. According to him, the root of this evil is the loss of spiritual and ethical values. This claim reveals that for the pope, the human person is spiritual and moral, and the person's resort to using illegal drugs or drug abuse is a rejection of his nature.

In his philosophical work, Karol Wojtyla elaborates on the nature of the human person, especially of the significance of the human body. Karol Wojtyla $(1979,136)$ writes:

Obviously, we cannot discuss the human body apart from the whole that is man, that is, without recognizing that he is a person. Neither can we examine the dynamisms and potentialities proper to the human body without understanding the essentials of action and of its specifically personal character. In this connection, it seems appropriate to recall the vision of the human reality advanced in the traditional philosophy of Aristotle and Aquinas, which from the likeness of man to the other beings of the visible world discovers in him alongside of the hylic or material element also the element of morphe or form; hence the theory of hylomorphism and the analysis of the human being carried out within its frame.

Malgorzata Jalocho Palicka (2017, 102-105) explains that for Wojtyla, the human body and the human soul are one and indivisible. The body without the soul is not a human person. The soul is the principle of life. It is that which gives life and 
form/essence to the body. In other words, it defines or makes the body not just any kind of body but a human body or a human person or a subject-someone and not something. By nature, the soul is spiritual or immaterial. Unlike the body, it is indivisible, it is not signed or characterized by quantity, and it does not perish. Since it is spiritual, it is capable of abstraction. It can know and pursue immaterial realities such as the Truth and the Good as its proper ends. Consequently, drug abuse or the use of prohibited drugs is contrary to the appropriate ends of the spiritual soul of the human person because it is not the real or genuine good. It is merely an apparent good, which is evil because it can harm and even kill the human person.

One aspect of the human person that enables him to have an objective awareness of the good and experience the good is consciousness. Wojtyla $(1979,35)$ claims:

Thus consciousness, owing to its mirroring function closely related to self-knowledge, allows us, on the one hand, to gain an objective awareness of the good or evil that we are the agents of in any particular action - while, on the other hand, it enables us to experience the good or evil in which its reflexiveness is manifested.

According to John Coughlin (2003, 67-68), John Paul II spouses the Aristotelian Thomistic notion that the human person is endowed with two major faculties: the intellect and the will or free will. The intellect enables the human person basically to think, to apprehend reality, make judgments, do reasoning, and know the truth as its proper object or end. The will or free will is that which enables the human person to act or to choose or pursue the Good as its proper object or purpose, which is identified by the intellect as Truth. With the intellect and will, the human person can do moral acts that are conscious, deliberate, voluntary, and culpable, which makes the human person a moral being. Hence, the human person has the inherent power to know the Truth and the Good and choose and pursue them as ends. In connection to this, the Filipino, as a human person who possesses the intellect and free will, is a moral being capable of knowing, discerning, and pursuing the Truth and the Good as ends. Therefore, he or she has the power to intrinsically and extrinsically abhor and evade the use of prohibited drugs, which he can know through his intellect as something harmful to himself and others.

John Paul II (1979), in his Encyclical letter "Redemptor Hominis," states, "Jesus Christ meets the man of every age, including our own, with the same words: "You will know the truth, and the truth will make you free." These words contain both a fundamental requirement and a warning: the requirement of an honest relationship with regard to truth as a condition for authentic freedom, and the warning to avoid every kind of illusory freedom, every superficial unilateral freedom, every freedom that fails to enter into the whole truth about man and the world. Today also, even after two thousand years, we see Christ as the one who brings man freedom based on truth, frees man from what curtails, diminishes, and as it were, breaks off this freedom at its root, in man's soul, his heart and his conscience." For Coughlin (2003, 70-71), John Paul II acknowledges that the human person is bestowed with freedom. Freedom naturally and necessarily flows from the human person's having an intellect and free will." Human freedom implies both the negative and positive meanings of freedom. The former means the freedom from or 
freedom against or the absence of constraints by an authoritarian regime or law. The latter means the freedom for or the inherent power or design of the person's intellect and will to know, choose, and pursue the Truth and Good as proper ends. Thus, freedom is not the license to do whatever one wants and wills, but rather it is always bound within the confines of the truth and the Good; that is why one is not free to do evil.

This means that the Filipino being a human person, has freedom from drugs. That is, the influence of drugs does not constrain him or her. He or she has the inherent power to resist it, to avoid it, and get out of it. The Filipino also has the freedom for the Truth and the Good. This means that the true Freedom of the Filipino rests in choosing the truth and the good. Since drug abuse is neither true nor good, therefore, to choose drugs is not aligned to the Filipino's authentic freedom.

Indeed the human person for John Paul II is both a corporeal and a spiritual being. John Paul II (1986) says: "Created in the image of God, man is both a corporeal and spiritual being. Bound to the external world, he also transcends it. Besides being a bodily creature, as a spirit, he is a person. This truth about man is an object of our faith, as is the biblical truth about his being constituted in the "image and likeness" of God. It is a truth constantly presented by the Church's Magisterium during the course of the centuries."

Moreover, the human person's spiritual nature is the foundation of his dignity, as John Paul II (1986) puts it: "Nevertheless we can easily deduce from it that the life given to man in the act of creation transcends the mere corporeal dimension (that which is proper to animals). Beyond the material, it reaches the dimension of the spirit, which contains the essential foundation of that "image of God," which Genesis 1:27 sees in man."

Palicka (2017, 103-105) confirms that for John Paul II, the human person's spiritual soul is that which gives the human body its dignity or inherent and inviolable value or worth that deserves the utmost respect. Being informed by a spiritual soul makes the body unique, different, and transcendent to any kind of material or corporeal entity. Both Nolan (n.d., 10) and Coughlin (2003, 71) affirm that John Paul II believes that the human soul is indeed unique, diverse, and transcended because it is fashioned in God's image. In other words, the human soul is an imago Dei. This makes the human soul and human life sacred, holy, precious, unique, and noble.

Since the human body is one with the human soul, therefore the body is also sacred, dignified, and worthy of utmost respect. Whatever affects the body also affects the soul and the whole human person. Thus, Drug abuse, which harms the body, also harms the soul, human life, and the human person as a whole. Since it can damage the body, the soul, life, and the human person, it is equivalent to disrespecting or neglecting the dignity of the human body, of life, of the human soul, and of the whole person. In line with this, The Filipino as a human person has dignity. This calls for the respect of one's body, soul, life, one's whole self, and others by not taking prohibit drugs and by leading others away from drugs.

John Paul II has always advocated respect for the dignity of the human person and respect for the fullness of life. In his encyclical letter "Evangelium Vitae, " John Paul II (1995) declares:

Man is called to a fullness of life that far exceeds the dimensions of his earthly existence because it consists in sharing the very life of God. 
The loftiness of this supernatural vocation reveals the greatness and the inestimable value of human life even in its temporal phase. Life in time, in fact, is the fundamental condition, the initial stage, and an integral part of the entire unified process of human existence. It is a process which, unexpectedly and undeservedly, is enlightened by the promise and renewed by the gift of divine life, which will reach its full realization in eternity (Cf. 1 Jn 3:1-2)."

Jean Claude Lavigne (2010) elucidates that John Paul II proclaims that the dignity of the human person is a gift of God. Because of that, it is neither formed by nor originated from any social, economic, or political affairs, entities, and institutions. The human person's dignity is universal, meaning every human being shares the same dignity as persons regardless of sex, culture, race, economic status. Any attempt or action that seeks to destroy or diminish this dignity is evil. Since drug abuse harms and even kills the human person, it undermines and destroys human dignity; therefore, it is evil.

\section{THE DRUG WAR IN THE PHILIPPINES AND KAROL WOJTYLA'S PHILOSOPHY OF THE HUMAN PERSON}

Human Rights Watch (n.d) declares that when President Duterte held office on June 30, 2016, as the new president of the Philippines, he initiated a campaign against drugs known as the "The War on Drugs." This campaign cost the lives of more than twelve thousand Filipinos, especially those coming from low-income families. Around two thousand five hundred fifty-five deaths have been ascribed to the Philippine National Police (PNP). The president himself instigated the said killings. He gave the police and the citizens the signal to slaughter drug users and drug pushers. According to Danilo Andres Reyes $(2016,1)$, Duterte said that the lives of these users, dealers, and the like are without value because they do not have any chance of redeeming themselves and or being redeemed by others. The president sees drug pushers, drug users, and criminals no longer as persons but as animals.

John Gershman (2016) narrates that the drug campaign is the cornerstone of Duterte's national policy because he believes that drug trade and use are chief impediments to the development of the country. The use and abuse of illegal drugs will lead to other crimes such as murder and rape, and therefore, it must be stopped immediately, and the only way to do it is to kill drug users and dealers. This policy is an extension of the system he implemented when he was still the chief executive of the City of Davao, which he believed is efficient and expedient.

Reuters (2019) adds that what is surprising is that the vast majority of the Filipinos, based on a study by the Social Weather Stations, gave the president an "Excellent" rating for the ongoing campaign on drugs. Eighty-two percent of the respondents strongly believed that the president's war on drugs has and significantly decreased drugs and crime in the country. Despite criticism and condemnation by the international community, Duterte and his administration ignore them and continue head-on with the campaign. 
In his message for the celebration of World Youth Day of Peace on January 1, 1999, John Paul II again asserts the innate dignity of the members of the human family and their inalienable rights, which are the very foundation of liberty, justice, and peace in the world. He (1999) says:

The year 1998 has marked the fiftieth anniversary of the adoption of the Universal Declaration of Human Rights. The Declaration was intentionally linked to the United Nations Charter since it shares a common inspiration. As its fundamental premise, it affirms that the recognition of the innate dignity of all members of the human family, as also the equality and inalienability of their rights, is the foundation of liberty, justice, and peace in the world. All the subsequent international documents on human rights declare this truth anew, recognizing and affirming that human rights stem from the inherent dignity and worth of the human person.

Gerald Beyer (2014, 72-91) elaborates that for John Paul II, the human person has rights, and these rights emanate from his dignity. These rights are given to him by the Creator as his spiritual soul is created in the likeness of God. Among the human person's rights are the right to life, the right to have the material needs to survive, the freedom of conscience, the right to the freedom of religion, the right to private property, the right to just wage, the right to organize, the right to freedom of speech and writing, and the right to participate in the common good. The Church, in unity with the world, has to protect human rights because if human rights are not protected, human dignity is also not protected from all dangerous assaults like pollution of the natural environment, wars, and the disrespect of the life of the unborn. This can happen if there is a denial of truth, the rejection of the human person's dignity. Human rights will continue to be indefensible if human dignity and God are not acknowledged as bases of these human rights.

In the same message, John Paul II (1999) mentions, "The first of these is the basic right to life. Human life is sacred and inviolable from conception to its natural end. "Thou shalt not kill" is the divine commandment that states the limit beyond which it is never licit to go. "The deliberate decision to deprive an innocent human being of life is always morally evil." Beyer (2014, 72-91) expounds that John Paul II acknowledges that the right to life is the most basic of all rights. If this primary right is not protected, all other rights will be in danger because it will lead to total relativism. That is to say, to deny the right to life is tantamount to denying all other rights.

Lavigne (2010) recounts that in John Paul II's speech addressed to the United Nations General Assembly on October 5, 1985; he presented the pressing concern of denial of the universality of human rights around the world. He affirms that the denial of human rights is itself the denial of human dignity and human nature from which human rights naturally flow or originate.

Silvio Cajiao (2003) says that John Paul II, in his message on January 1, 1988, during the World Day of Peace, specified that the inalienable rights of the human person are the basis of social order. Since these rights come from the human person's very essence and dignity and the incarnation of Christ, these rights are not external to 
the human person, and thus no foreign power or authority can make it null and void. In other words, it is something inviolable. The only way to achieve peace is to acknowledge and respect these inalienable rights. Lavigne (n.d) articulates that according to John Paul II, no one is entitled to attack human rights and human dignity, and the government should safeguard human rights and human dignity at all cost. The state should be expected to defend human rights and human dignity through laws, police power, education, and the justice system. Therefore, the death penalty is unacceptable.

This drug campaign by president Duterte and his administration that lead to the extermination of the suspected drug pushers, dealers, and users throughout the archipelago through police operations and vigilante-style extrajudicial killings is like the death penalty. It is a clear violation of human rights, especially the right to life. As stated previously, if the right to life is violated, all other rights are also violated, and whatever violates human rights also violate human dignity. So, this war on drugs is indeed a violation of human dignity. More so that it has reduced the victims who human persons are into objects or mere numbers in the statistics of the campaign. Likewise, the support of the majority of the Filipinos to the drug war is a degradation of human rights and human dignity. It is a vivid elucidation of the lack and the distorted comprehension of the human person as if the person is merely disposable and can just be exterminated any time when he or she is deemed useless or dysfunctional by the leaders and members of society.

The drug dealers, pushers, and users are human persons with inalienable and inviolable rights and dignity and, therefore, do not deserve to be killed and murdered. The Filipino, who is a human person, has the duty or obligation to protect the rights and dignity of a man at all costs. It is also the duty of the Philippine government, which is a democratic state whose authority is derived from the Filipino people who are themselves, human persons, to protect human rights and human dignity by not resorting to or approving the extermination of drug dealers and drug users through extrajudicial killings or by any other means.

\section{HIV AND AIDS IN THE PHILIPPINES AND KAROL WOJTYLA'S PHILOSOPHY OF THE HUMAN PERSON}

The Department of Health (n.d.) presents the UNAID report, which shows that the increase of the HIV epidemic in the Philippines is considered the fastest in terms of percentage of the figure of new infections in the Asia-Pacific region. Though these reports show that the country was able to control the spread of the virus among female sex workers, however, the spread of the virus is escalating among males having sex with males (MSM) and transgender women who have sex with males (TGW) than among persons who inject drugs. What is alarming is that these recent infections are mostly transmitted among fifteen to twenty-four-year-old MSM and TGW. For this reason, HIV is a leading health priority of the government. Having identified sex as the primary transmitter of HIV and AIDS in the country, especially with men having sex with men and transgender women having sex with men, indicates a crisis of the philosophy of the human person. 
In his work Ecclesia in Africa, John Paul II (1995) attributes the spread of AIDS to the irresponsible sexual behavior of the human person. This shows that for him, the human person is a sexual being. John Paul II, in Love and Responsibility (1993), upholds that the human person is a sexual being and has a sexual drive or passion. However, sexuality and the sexual drive are not evil in themselves, but rather good because the Creator designed them for a specific purpose, and that is for the human person to become procreators of his kind. The proper end or purpose of sexual intercourse is procreation, and that should be within the bounds of marriage. In marriage, the human body and human sexuality are considered gifts to be given between a man and a woman as acts of free and total self-giving of each other out of love.

Hence, to have sex outside marriage like that of MSM and TGW and for the sake of lust or sexual gratification violates the fundamental purpose of human sexuality and sexual intercourse and constitutes irresponsible sexual behavior. On the contrary, what is proper to a human person is to have responsible sexual behavior, which is to act and guide one's sexual drive through the right reason for the sole purpose of procreation within marriage.

In the same work, Love and Responsibility, John Paul II $(1960,26)$ insists, "A person must not be merely the means to an end for another person. He $(1960,27)$ adds, "Anyone who treats a person as the means to an end does violence to the very essence of the other." Moreover, he $(1960,27)$ continues, "Nobody can use a person as a means towards an end, no human being, nor yet God the Creator." William E. May (2007) expounds on John Paul II's idea that the human person is a subject and not an object and should not be treated as a tool, instrument, or a sex-machine. Since human persons are subjects, they must be treated not as means but as ends. To have sex with a sex worker or a partner just for the sake of sexual gratification is using the person as objects or as a means to an end. Therefore, a transgression of human dignity and human nature.

Also, John S. Grabowski (n.d.) explains that John Paul II teaches that the body is the expression of the soul and the person's dignity. Through the body, the person discovers his dignity and its faculty to think and will, which animals lack. Hence, the body of the human person in itself has dignity. Dignity demands that it be respected and not to be used as merely as an object of desire. Every time the Filipino indulges himself or herself in sexual intercourse outside marriage or for the sake of sexual gratification violates the dignity of the body and the dignity of the person as a whole. Ergo, MSM, and TGW, which are acts outside marriage and whose purpose will not align with the real purpose of sexuality and sexual act, which is procreation violates human dignity.

Moreover, Charles E. Curran (2003, 618-620) concurs that John Paul II is not really negative about passion and acknowledges it as part of human sexuality. However, John Paul II emphasizes the necessity of self-control, self-discipline, and the need for human sexuality to be guided by reason towards its true purpose and goal. Through the human person's spirit and reason, he or she can know and choose the Truth and the Good and can discern the real purpose of one's sexuality. In this regard, the human person has the self-mastery or the power to control, govern, and guide one's sexual drive or passion according to the dictates of reason. Hence, the Filipino as a human person has the inherent power to discipline or control one's passion or desire 
and guide it to its proper end, which is procreation within marriage, and avoid SMS, TGW, and any kind of sex outside marriage. By doing, so the Filipino can prevent the spread of AIDS and HIV.

\section{FAKE NEWS IN THE PHILIPPINES AND WOJTYLA'S PHILOSOPHY OF THE HUMAN PERSON}

Rae Ann Varona (2018) presents a survey conducted by the Social Weather Stations (SWS) between December 2017 to March 2018 from among 1,200 respondents (eighteen years of age and older) through interviews within the Philippines, which shows that Fakes News is a severe problem in the country.

Lorenzo Flores (n.d) provides a definition of Fake news or false news as stories or hoaxes to deliberately misinform or disinform, which is to deceive readers in any media platform. It is an online phenomenon that has a severe real negative consequence. It promotes publicity, influences elections, misrepresents the truth, and destroys people. It can be weaponized by militants and terrorists, subvert the democratic process, and wither trust in media as the watchdog of society. It is even used by populist administrations to deny allegations of injustice and human rights violations committed by them.

Maria Ressa (2017) and her team (Rappler) have identified at least three hundred websites diffusing fake news in the country. Fake News in the country is mainly used to influence voters, target politicians, and individuals, especially during the May 2016 elections. Fake news was also found in different Filipino organizations abroad and online business groups. There are an estimated fifty-four million Facebook users in the country. Social media has become a compelling platform to repress opposition and mold the perspectives of the people. Fake news is used to harass and attack news reporters and contributors.

In the age of fake news, many Filipinos, especially those who are responsible for the creation and proliferation of fake news on whatever platform, have lost sight of the truth and have betrayed their nature as human persons. In John Paul II's (1998, 45-50) view, the human person yearns to know, and the proper object of this yearning is no other than the truth. Based on everyday experience, human persons abhor and reject falsity and find reward and fulfillment in the truth. One of the measures of adulthood is the ability to distinguish between falsehood and truth. Hence, the human person is not only capable of knowing the truth; he is also capable of knowing himself and is concerned with knowing the truth of his perception. For this reason, he defines the human person as the one who pursues the truth; in other words, a seeker of Truth. The human person is ordained to know and seek the truth. Therefore, not being able to understand and follow or choose the truth is contrary to his nature.

Alice Ramos $(1995,114)$ conveys that for Wojtyla, truth is not just the conformity of thought to things, but it is the same as the good. It is the good perceived by the intellect as the proper object or end of the will. Hence, evil is not the truth. To be true is to be good, that is to act in harmony with the natural law, the law of morality and wisdom of God-endowed in the minds and heart of the human person. Fake news in intention, in itself and its result, is evil; therefore, it can never be the truth. 
As discussed previously, the Truth and the Good are the proper objects, goals, or ends of the human person's spiritual faculties. These faculties had been designed by the Creator to be geared towards these goals. Hence fake news that is contrary to the proper ends of the human person's intellect and will is contrary to human nature and is therefore to be loathed and avoided at all cost. In short, the Filipino who is a human person is a seeker of truth and not a promoter or advocate of fake news.

The human person is indeed a seeker of the absolute truth, and his desire for it can never be taken away, not by error or sin. John Paull II, in his encyclical letter "Veritatis Splendor" (1993), explains this very clearly.

But no darkness of error or of sin can totally take away from man the light of God the Creator. In the depths of his heart, there always remains a yearning for the absolute truth and a thirst to attain full knowledge of it. This is eloquently proved by man's tireless search for knowledge in all fields. It is proved even more by his search for the meaning of life.

Ramos (1995, 114) clarifies that for John Paul II, God Himself is the Truth or Ultimate Truth. This means that the human person is not only a seeker of truth but a seeker of God as his Ultimate End. So, man is a Religious Being, a being intrinsically connected and destined to with God. Thus, the vocation and destiny of the human person are to be holy, perfect, True, Good, and Godlike. To be a creator and promoter of fake news is nowhere close to being Godlike. Ergo, to create and propagate fake news is not proper to the human person. The Filipino is a human person, he or she does not deserve fake news, and it is not appropriate for him to create and propagate it.

\section{HUMAN-INDUCED CLIMATE CHANGE IN THE PHILIPPINES AND KAROL WOJTYLA'S PHILOSOPHY OF THE HUMAN PERSON.}

The Philippine Atmospheric, Geophysical, and Astronomical Services Administration (PAGASA) (n.d.) claims that climate change is happening here and now, and evidence shows that natural variations cannot just explain it. The majority of scientific studies and their findings affirm or support that an increase in the earth's temperature is most probably caused by human beings, such as fossil fuel consumption and land-use change. This poses a significant threat to humanity and the world and will become worse over time.

The Climate Reality Project (2016) declares that the impact of climate change in the country is devastating because, in recent years, the country has experienced more violent storms like Typhon Yolanda or Typhon Haiyan. This means more storm surges and flooding, which significantly affect the population. More destructive typhoons caused by climate change would hurt the economy. Not only will it destroy agriculture, infrastructure, industries, and livelihood, it charges the country two percent of its GDP. It will also cost more or less another two percent to rebuild damaged infrastructures. What is alarming it causes more human casualties than ever before.

Rappler (n.d.) opines that the country's main sectors that contribute to climate change are 1) Energy. The primary source of energy in the Philippines comes from 
coal-fired power plants and other fossil fuels, 2) Forestry. Many forests in the Philippines are cleared due to illegal logging and plantation. These activities reduced the country's forest cover from 1934-2010, 3) Agriculture. Rice plantation in flooded areas requires more fertilizers to grow. This emits methane gas when the fertilizers decompose, 4) Transportation. Most of the vehicles in the Philippines run mainly on oil and petroleum products. There are more private cars in the country than mass transport. This emits more carbon dioxide into the atmosphere, 5) Mineral production and Mining, 6) Waste. The Philippines throw waste in open dumps and in landfills instead of being reused, recycled. They also emit more methane gas.

Tracy G. Mehan (2005) recounts that John Paul II's message during World Youth Day on January 1, 1990, emphasizes the new ecological awareness due to the lack of respect for nature. In his review of the creation story and story of salvation, the pope concluded that every time man sins, a man had provoked a disorder that inevitably harmed the whole of creation, which is an ecological crisis. He affirmed that humanity should restore the health of the environment, for it is the responsibility of the Christians to God and His creatures.

Mehan (2005) added that in the encyclical "Centesimus Annus," John Paul II speaks of the ecological question as something that is equally worrying as the problem of consumerism for the two are intimately connected. In man's desire to have and enjoy, man has exploited the earth and depleted its resources. The pope describes this abuse of the environment to be senseless and an "anthropological error."

On March 24, 1997, during the Conference on Environment and Health, John Paul II (1997) notes that the environmental exploitation and conquest has undeniably become predominant and invasive that has now become threatening to the earth as the "Home" of humanity. Due to the powerful transformation caused by technological civilization, the equilibrium between humanity and the environment has reached its tipping point. He continued that the secularized modern age has two new temptations: one is a concept of knowledge that is not a product of wisdom and contemplation whose goal is to dominate nature, which is regarded as a raw material to be consumed. Another is the uncontrolled abuse of the resources of the earth under the influence of profitseeking in line with the capitalistic mentality common among modern societies. Because of these temptations, the earth's environment has been consumed by the interest of a few, particularly the wealthy industrialists, to the disadvantage of the entire humanity. This demands human responsibility and not just any kind of responsibility but a concerted effort to protect life and ensure a sustainable future for the poor and the next generation.

To do this, John Paul II (1997) proposes that it requires a solid foundation that is an explicit knowledge of human dignity and God's plan of creation that will inspire humanity to take care of the earth. It is only when a man sees the face of God in creation that he can ensure environmental hospitality today and tomorrow. He (1997) uses the idea of biblical revelation to illustrate that the environment, the whole of creation, is good because it comes from God and is created out of God's love for humanity. Likewise, he used anthropology based on sacred scriptures to explain that the human person by his spirituality is created in God's image and, therefore, can transcend worldly realities and can become a responsible custodian of the environment. As a consequence, the human person's relationship with other human beings and with the 
earth is determined by his relationship with God. Man must recognize that the whole of creation is God's gifts to be valued, protected, and nurtured

In his encyclical letter Evangelium Vitae, John Paul II (1995) also affirms man's ecological responsibility and stewardship, which is based on his dignity. Just as God cares for his creation, so does a man who is like God and destined to be with God.

Lavigne (2010) likewise asserts that John Paul II speaks of the protection and promotion of human rights and human dignity as indispensable to the authentic and full development of the human persons or the human person's self-fulfillment. When he speaks of self-fulfillment or positive development, he refers to holistic or integral human development. Comprehensive human development includes not only the economic, biological, cultural, social, political, but also ecological and environmental development, which entails the protection and preservation of the natural environment.

John Paul II's notion of self-fulfillment can be traced back to his discussion of the nature of human action as a revelation of his nature as a human person. Human action reveals the person; it is because man acts that we know him to be a human person; his action also reveals that he is the agent of his acts. By acting, the human person is fulfilled or actualized. Wojtyla $(1979,10)$ says:

"In our study, on the other hand, the aim is to reverse this relation. The title itself of this book, The Acting Person, shows it is not a discourse on action in which the person is presupposed. We have followed a different line of experience and understanding. For us, action reveals the person, and we look at the person through his action. For it lies in the nature of the correlation inherent in experience, in the very nature of man's acting, that action constitutes the specific moment whereby the person is revealed. Action gives us the best insight into the inherent essence of the person and allows us to understand the person most fully. We experience man as a person, and we are convinced of it because he performs actions."

In Nolan's (n.d., 7) view, Wojtyla defines the person as not just a conglomeration of emotions but rather an agent who acts rather than merely a passive recipient of an action. As an active agent, the human person lives in a community and society, and he is not only concerned about his good but is concerned with the good of others or the common good of all through the discernment of his intellect and will. Hence, the person naturally participates in the community for its common good. Lavigne (n.d.) supports the idea that John Paul II considers the human person as a social being and not a solitary being. If human persons have the same universal rights and dignity, they form a community of shared essence whose relationship is not merely a collection of anonymous objects but anchored on mutual respect and love. The basis of this community or the relation of persons as persons is the relationship of the Triune God through love. Each human person has the right to be part of the human community and to be benefitted from the love of others in society, especially the marginalized, the poor, and the least. Therefore, the essence of being social or being part of the human community is to participate in the community through love. 
Lavigne (2010) further explains that for John Paul II, the loving relationship of human persons in a community through their acts of participation leads to mutual relationships that bring for the common good. John Paull II subscribes to the definition of common Good in "Gaudium et Spes," which is a result of the social conditions that enable people or groups to achieve smooth and full authentic development or fulfillment. The common good is the protection and promotion of human rights and human dignity. This can be attained only in the context of the community and not through individualism. In his message for the World Day of Peace, John Paul II (1990) posits:

"On the other hand, the earth is ultimately a common heritage, the fruits of which are for the benefit of all. In the words of the Second Vatican Council, "God destined the earth and all it contains for the use of every individual and all peoples" (Gaudium et Spes, 69). This has direct consequences for the problem at hand. It is manifestly unjust that a privileged few should continue to accumulate excess goods, squandering available resources, while masses of people are living in conditions of misery at the very lowest level of subsistence. Today, the dramatic threat of ecological breakdown is teaching us the extent to which greed and selfishness - both individual and collective - are contrary to the order of creation, an order which is characterized by mutual interdependence."

Lavigne (2010) expounds that John Paul II thinks that the ecological good is part of the common good because the entire creation has been bestowed to humanity as a gift from God, not just to an individual human person as a beneficiary. Hence, it the responsibility of the entire human race, regardless of sex, status, and color, to take care of the whole of creation as a gift from God. So, the planet itself is a common good that belongs to the whole of humanity, not just to the elite and the powerful. Sustainable development is only possible if it is aimed towards the common good.

It is evident that for John Paul II, the human person is a steward not just of the environment but the whole of creation. Thus, the Filipino is the custodian of the environment and the whole of nature. It is his or her duty to protect the environment from degradation and abuse.

\section{CONCLUSION}

Based on Karol Wojtyla's philosophy of the human person, The Filipino is essentially a human person who is a subject and not an object. Hence, he has to treat himself and others not as a means but as an end. As a human person, the Filipino is endowed with the intellect and will, which make him/her a rational and moral being capable of knowing, discerning the truth, and choosing the Good as his/her proper ends. With his intellect and will, he a seeker of the truth, and he is free; that is, he has a master of himself, he has the power to govern himself and pursue the proper ends of one's intellect and will. As a human person, the Filipino has inalienable rights and dignity that are inviolable. His dignity demands the utmost respect and value of oneself 
and others. The Filipino is created in God's image and likeness. The purpose of his or her existence is to know, choose, love God, and to become like God. The Filipino as a human person is also a social being. He is called to participate and act in a community for its common good. Part of this common Good is ecological good. Ergo, the Filipino is a steward of all creation.

Karol Wojtyla sees the Filipino as inherently good and is capable of knowing and choosing the Good and choosing God. Therefore, Karol Wojtyla believes that the Filipino can overcome and transcend the problems of society by knowing and discerning the truth, choosing the good and God. In others, he can overcome issues of his community by acting according to his nature as a human person. The solution to his or her problems is within himself, within his or her freedom and choice.

Karol Wojtyla's philosophy of the human person has shown the Filipino how it is to be truly human and, therefore, to be truly Filipino. To reeducate the Filipino on how to be truly human and to be truly Filipino, this paper recommends that Karol Wojtyla's Philosophy of the human person be integrated into the philosophy courses of the senior high school programs and the general education courses such as Ethics and Understanding the Self in the tertiary level in Philippines Catholic schools, colleges, and universities.

\section{REFERENCES}

Aguas, Jove Jim. 2009. The notions of the human person and human dignity in Aquinas and Wojtyla. Kritike: An Online Journal of Philosophy, 3(1):40-60. http://www.kritike.org/journal/issue_5/aguas_june2009.pdf. Accessed: December 18, 2020.

Beyer, Gerald J. 2014. John the XXIII and John Paul II, the human rights popes. Ethos 27: 2014 No. 2(106):192-140.DOI 10.12887/27-2014-2-106-04. Accessed: December 30, 2019.

Cajiao, Silvio. 2003. Human rights in the teachings of John Paul II. http://www.clerus.org/clerus/dati/2003-11/05-13/07Pa25IN.html. Accessed: December 30, 2019.

Climate Reality Project. 2016. How is climate change affecting the Philippines? https://www.climaterealityproject.org/blog/how-climate-change-affectingphilippines. Accessed: December 28, 2019.

Coughlin, John J. 2003. Pope John Paull II and the dignity of the human being. Notre Dame Law School NDL Scholarship. 27 Harv. J.L. \& Pub. Pol'y 65 (2003-2004): 65-79. https://scholarship.law.nd.edu/law_faculty_scholarship/494. Accessed: December 27, 2019.

Curran, Charles E. 2003. Pope John Paul II's teaching on sexuality and marriage: An appraisal. University of St. Thomas Law Journal. Volume 1. Issue1 Fall 2003. https://ir.stthomas.edu/cgi/viewcontent.cgi?article=1026\&context=ustlj.

Accessed: December 29, 2019.

Danganan, Juzel. 2017. Illegal drugs and its ill effects. Philippine News Agency (PNA). https://www.pna.gov.ph/articles/1017569. Accessed: December 27, 2019. 
de Santos, Jonathan. 2019. PNP, PDEA, NBI agree: Duterte's estimate of $8 \mathrm{M}$ drug users has a basis. https://www.philstar.com/headlines/2019/02/28/1897470/pnppdea-nbi-agree-dutertes-estimate-8m-drug-users-has-basis. Accessed: December $27,2019$.

Department of Health. n.d. Philippines addresses rising trend in new HIV infections. Available at Doh.gov.ph/node/10649. Accessed: December 17, 2019.

Flores, Lorenzo. n.d. Fake News: Why does it persist and who's sharing it. https://thedecisionlab.com/fake-news-why-does-it-persist-and-whos-sharing-it. Accessed: December 22, 2019.

Gershman, John. 2016. Human rights and Duterte's war on drugs. https://www.cfr.org/interview/human-rights-and-dutertes-war-drugs. Accessed: January 1, 2020.

Grabowski, John S. (n.d). The Theology of the Body according to St. John Paull II. https://www.foryourmarriage.org/the-theology-of-the-body-according-to-popejohn-paul-ii/. Accessed: December 18, 2019.

Hembra, Mariano S. 2004. Social, political, and economic context of illegal drug abuse in the Philippines. https://www.drugabuse.gov/international/abstracts/social-political-economiccontext-illegal-drug-abuse-in-philippines. Accessed: December 27, 2019.

Human Rights Watch. Philippines' war on drugs. https://www.hrw.org/tag/philippines-war-drugs. Accessed: December 31, 2019.

John Paul II. 1960. John Paul II on Love and responsibility. Love \& Responsibility Foundation, New York. https://www.jp2.info/JP2_on_Love-Responsibility.pdf. Accessed: November 4, 2020.

John Paul II. 1979. Redemptor Hominis. http://www.vatican.va/content/john-paulii/en/encyclicals/documents/hf_jp-ii_enc_04031979_redemptor-hominis.html. Accessed: December 30, 2019.

John Paul II. 1986. Humans are spiritual and corporeal beings. Catechesis on Creation. $\quad$ http://inters.org/John-Paul-II-Catechesis-Spiritual-Corporeal. Accessed: December 18, 2020.

John Paul II. 1987. Address of the Holy Father John Paull II to the representatives of the International Conference on Drug Abuse and Illicit Trafficking. Libreria Editrice Vaticana. http://www.vatican.va/content/john-paulii/en/speeches/1987/june/documents/hf_jp-ii_spe_19870604_conferencedrugabuse.html. Accessed: December 19, 2020.

John Paul II. 1990. Message of His Holiness John Paul II for the celebration of the World Day of Peace January 1, 1990. http://www.vatican.va/content/john-paulii/en/messages/peace/documents/hf_jp-ii_mes_19891208_xxiii-world-day-forpeace.html. Accessed: November 4, 2020.

John Paul II. 1993. Veritatis splendor. http://www.vatican.va/content/john-paulii/en/encyclicals/documents/hf_jp-ii_enc_06081993_veritatis-splendor.html. Accessed: November 4, 2020.

John Paull II. 1995. Post-Synodal Apostolic Exhortation Ecclesia in Africa of the Holy Father John Paul II to the bishops, priests and deacons, men and women religious and all the lay faithful on the Church in Africa and its evangelizing mission towards the year 2000. http://www.vatican.va/content/john-paul- 
ii/en/apost_exhortations/documents/hf_jp-ii_exh_14091995_ecclesia-inafrica.html. Accessed: December 17, 2019.

John Paul II. 1995. Evangelium vitae. http://www.vatican.va/content/john-paulii/en/encyclicals/documents/hf_jp-ii_enc_25031995_evangelium-vitae.html. Accessed: November 4, 2020.

John Paul II. 1997. Address of His Holiness John Paul II to the Conference on Environment and Health. Libreria Editrice Vaticana. https://w2.vatican.va/content/john-paul-

ii/en/speeches/1997/march/documents/hf_jp-ii_spe_19970324_ambientesalute.html. Accessed: December 28, 2019.

John Paul II. 1998. Fides Et Ratio. Pasay City, Philippines: Paulines Publishing House. John Paul II. 1999. Message of His Holiness Pope John Paul II for the Celebration of the World Youth Day of Peace January 1, 1999. http://www.vatican.va/content/john-paul-ii/en/messages/peace/documents/hf_jpii_mes_14121998_xxxii-world-day-for-peace.html. Accessed: November 4, 2020.

Lavigne, Jean Claude. 2010. The human person and the common good in the social teachings of John Paul II. Oikonomia: Journal of Ethics \& Social Sciences. Giugno 9(2). https://www.oikonomia.it/index.php/en/oikonomia-2010/giugno2010/701-the-human-person-and-the-common-good-in-the-social-teaching-ofjohn-paul-ii. Accessed: January 2, 2020.

May, William E. 2007. Karol Wojtyla's Love and Responsibility: A summary. http://www.christendom-awake.org/pages/may/summaryofl\&r.htm. Accessed: December 18, 2019.

Medina, Marielle and Antonio Rafael. 2014. Pope John Paul II's visits to P.H. Available at https://globalnation.inquirer.net/102782/pope-john-paul-iis-visits-toph. Accessed: January 14, 2020.

Mehan, Tracy G. 2005. John Paul II and the environment. Catholic Exchange. https://catholicexchange.com/john-paul-ii-and-the-environment. Accessed: December 28, 2019.

Nolan, Simon, O. Carm. n.d. The philosopher pope: Pope John Paull II and the human person. http://www.carmelites.ie/PhilosopherPope.pdf. Accessed: December 27, 2019.

PAGASA. Climate change in the Philippines. http://bagong.pagasa.dost.gov.ph/information/climate-change-in-the-philippines. Accessed: December 27, 2019.

Palicka, Malgorzata Jalocho. 2017. Spiritual substance: The essence of man person according to Karol Wojtyla. Studia Gilsoniana 6(:1): 102-105. http://cejsh.icm.edu.pl/cejsh/element/bwmeta1.element.desklight-d579a21f837f-42ab-bd25-a832709dd8b3. Accessed:18 December 2020.

Ramos, Alice. 1995. Karol Wojtyla-John Paul II's idea of ultimate reality and meaning. Ultimate reality and meaning. Vol 18, no. 2: 102-118. DOI: 10.3138/uram.18.2.102.https://www.utpjournals.press/doi/pdf/10.3138/uram.18. 2.102. Accessed: January 9, 2020.

Rappler. n.d. Climate change: Why P.H. should care. https://www.rappler.com/brandrap/climate-change. Accessed: December 29, 2019. 
Ressa, Maria. 2017. Fake news: sound bites on a burning topic. The UNESCO Courier. https://en.unesco.org/courier/july-september-2017/fake-news-soundbites-burning-topic. Accessed: December 28, 2019.

Reuters. 2019. Filipinos give thumbs up to Duterte's excellent drug war: poll. https://www.reuters.com/article/us-Philippines-drugs/Filipinos-give-thumbs-upto-dutertes-excellent-drugs-war-poll-idUSKBN1W803M. Accessed: January 1, 2020.

Reyes, Danilo Andres. 2016. The spectacle of violence in Duterte's war on drugs. Journal of Current Southeast Asian Affairs 35(3): 111-137. https://journals.sagepub.com/doi/full/10.1177/186810341603500306 Accessed: December 31, 2019.

Sfeir, Nasrallah Pierre.2003. Ecumenism in the Pontificate of John Paul II. https://www.ewtn.com/catholicism/library/ecumenism-in-the-pontificate-ofjohn-paul-ii-2258. Accessed: January 15, 2020.

Varona, Rae Ann. 2018. Fake news is a serious issue of concern for a majority of the Filipino, survey finds. https://www.asianjournal.com/philippines/metromanila/fake-news-is-a-serious-issue-of-concern-for-a-majority-of-Filipinossurvey-finds/.Accessed: December 21, 2019.

Weigel, George. n.d. Wojtyla's walk among the philosophers. https://eppc.org/publications/wojtylas-walk-among-the-philosophers/. Accessed: January 9, 2020.

Wojtyla, Karol. 1979. The acting person. Translated by Andrzej Potocki. Dordrecht, Holland; Boston, USA; London, England: D. Reidel Publishing Co.

Wojtyla, Karol. 1993. Love and responsibility. Translated by H.T. Willets. San Francisco: Ignatius Press. 